\title{
Major and some trace elements concentrations of Miocene-aged Alpu coals, Eskisehir, Turkey
}

\author{
Cigdem Saydam Eker ${ }^{1,}$, Ejder Yapici \\ ${ }^{1}$ Deparment of Geology, Gumushane University, Gumushane, Turkey \\ ${ }^{2}$ General Directorate of Mineral Research and Exploration, Ankara, Turkey
}

Email address:

csaydam@gumushane.edu.tr (C. S. Eker), csaydam@hotmail.com (C. S. Eker)

To cite this article:

Cigdem Saydam Eker, Ejder Yapici. Major and Some Trace Elements Concentrations of Miocene-Aged Alpu Coals, Eskişehir, Turkey. Earth Sciences. Vol. 3, No. 4, 2014, pp. 109-116. doi: 10.11648/j.earth.20140304.12

\begin{abstract}
Elemental contents, organic matter, and relation with Miocene-aged coal samples were analyzed in Alpu, Eskişehir, Turkey. The coal samples were identified as upper and lower seams in the $\mathrm{m} 2$ series. This series includes the following from the bottom to the top: claystone-marl, coal lower seam, sandstone, siltstone-claystone, upper coal seam, and claystone-sandstone-gravelstone. A total of 17 coal samples (eight and nine from the upper and the lower seam) were collected from five boreholes. Proximate and element analyses of the samples were performed and evaluated. In an airdried basis, the upper and the lower seam have low average moisture contents (about $8 \%$ and $6 \%$ ), average moderate ash yields (about $31 \%$ and $28 \%$ ), and high total average calorific values (about 3215 and $2934 \mathrm{kcal} / \mathrm{kg}$ ). The major elements found in Miocene-aged coal in this area are $\mathrm{Na}, \mathrm{Mg}, \mathrm{Al}, \mathrm{Si}, \mathrm{P}, \mathrm{K}, \mathrm{Ca}, \mathrm{Ti}, \mathrm{Mn}, \mathrm{Fe}$, and $\mathrm{S}$. Compared with the average world coal content, major elemental contents of the two seams have highly enriched levels. Some trace elemental contents (e.g., V, $\mathrm{Cr}, \mathrm{Ni}, \mathrm{Cu}, \mathrm{Zn}, \mathrm{Rb}, \mathrm{Sr}, \mathrm{Ba}, \mathrm{Pb}, \mathrm{Zr}$, and $\mathrm{As}$ ) of the studied coal samples indicate similarity between the two coal seams, which are highly depleted with respect to the world average. The Al and Si contents of both coal seams have positive correlations with the ash yield, whereas those of $\mathrm{Mg}, \mathrm{Na}, \mathrm{Ca}$, and Fe have negative correlations. The concentrations of $\mathrm{Ni}$ and $\mathrm{Ba}$ in these seams are positively correlated with the ash yield, and that of $\mathrm{Sr}$ and $\mathrm{Zr}$ have negative correlations.
\end{abstract}

Keywords: Coals, Proximate Analysis, Major and Trace Elements, Miocene, Alpu, Turkey

\section{Introduction}

Coal is a sedimentary rock associated with a complex heterogeneous mixture of organic and inorganic matter. Organic matter in coal comprises preserved or permineralized ancient plants or their fragments $[1,2,3,4$, 5]. Each coal deposit has individual plant precursors, as well as specific regional, depositional, and paleoenvironmental conditions. However, these deposits can cause enrichment or depletion of different elements, phases, or minerals [6]. Most elements have mineral matter affinity in coal, but certain elements are associated with organic matter. Elements having inorganic affinity become affected by combustion, but are mostly concentrated in ash $[7,8]$. This study aims to analyze the major and trace element concentrations of Miocene-aged coal samples in Alpu, Eskişehir, Turkey. Previous work has analyzed the geological setting, coal geology, and economical potential of this area $[9,10,11]$. In the Alpu coals, average total moisture, ash, fixed carbon contents, and total calorific values in the upper coal seam are higher than those in the lower seam. However, the average value of volatile matter content in the lower coal seam is higher than in the upper seam. Al and Si contents in both coal seams have positive correlations with ash yield. These elements are generally associated with inorganic components. The ash yields in the lower coal seams have positive correlations with $\mathrm{K}, \mathrm{P}$, $\mathrm{Ti}$, and $\mathrm{S}$. These elements are dominantly and inorganically associated. However, these contents in the upper coal seam have negative correlations with the ash yield. Ash yields of the coal samples in upper and lower seams have negative correlations with $\mathrm{Mg}, \mathrm{Na}, \mathrm{Ca}$, and $\mathrm{Fe}$. the concentrations of $\mathrm{Ni}$ and $\mathrm{Ba}$ in coal samples from both seams are positively correlated with the ash yield. These elements have inorganic affinity. The ash yields in coal samples from the upper seam have positive correlation with $\mathrm{Zn}, \mathrm{Cu}, \mathrm{Cr}$, and $\mathrm{V}$, suggesting a mineral matter affinity. $\mathrm{Zn}$ is mainly associated with the inorganic components in coal $[12,13$, 
14]. The organic associations of $\mathrm{Zn}$ have also been determined in low-ranked coals $[15,13,16]$. $\mathrm{Cu}$ and $\mathrm{Cr}$ in coal have organic affinity $[17,13,8]$. In addition, $\mathrm{V}$ in coal is associated with both inorganic and organic matter [17, 13]. The concentrations of $\mathrm{Sr}$ and $\mathrm{Zr}$ in both coal seams are negatively correlated with the ash yield, showing the association of these elements with organic matter. $\mathrm{Zr}$ is commonly associated with organic matter $[17,13,8]$. $\mathrm{Sr}$ is mainly found together with mineral matter, and is associated with organic matter in low-ranked coals $[17,13$, $18,8]$.

\section{Geological Setting}

The basement rocks of the study area comprise Triassicaged metamorphic rocks and Jurassic-Cretaceous ophiolite. These units are unconformably overlain by Miocene-aged sedimentary rocks named $\mathrm{m} 1, \mathrm{~m} 2$, and $\mathrm{m} 3$ sequences. The $\mathrm{m} 1$ series comprises red, brown, gray, yellowish gray, and greenish gray siltstone, sandstone, and semi-rounded gravelstone. The $\mathrm{m} 2$ unit mainly includes green gravelstone, dark green, and gray sandstone, siltstone, marl, and coalbearing claystone. Very thin limestone bands are locally observed in marl and claystone. The coal samples are deposited within this series. The $\mathrm{m} 3$ series, which is characterized by limestone and gravelstone, conformably overlies the $\mathrm{m} 2$ series and is unconformably covered by Quaternary alluvium (Figure 1).

The occurrences of Alpu coal in the Anatolids are found within the Miocene-aged $\mathrm{m} 2$ series. Two coal seam levels exist in each borehole, namely, the lower and the upper seam. The total thickness of the coal seams ranges from 1.2 $\mathrm{m}$ to $14.7 \mathrm{~m}$ for the lower seam, and $0.6 \mathrm{~m}$ to $15 \mathrm{~m}$ for the upper seam (Figure 2).

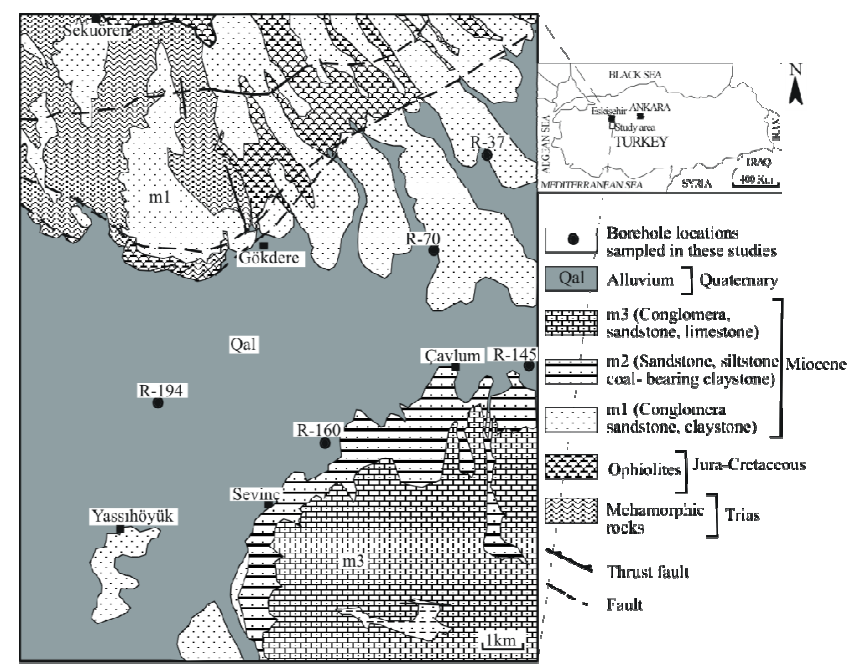

Figure 1. Geological map of the Alpu basin and locations of the boreholes sampled in this study.

\section{Methods}

Seventeen core samples (eight and nine coal samples from the upper and the lower seam) from five boreholes (R-37, R-70, R-145, R-160, and R-194) were collected from the Alpu field (Fig. 2). The boreholes were drilled by the General Directorate of Mineral Research and Exploration (MTA). Proximate analysis was performed on the coal samples. Atomic absorption spectrometry (AAS) and X-ray fluorescence (XRF) were performed using standard techniques at the MTA Laboratory. For proximate analysis, the calorific values were obtained using Leco AC 500 device with the standard set to ASTM 5865. Total moisture, volatile matter, and ash contents were measured using Leco TGA-701 device. Total sulfur content was determined using Leco-SC144DR device. AAS was used to analyze the major elements. $\mathrm{V}, \mathrm{Cr}, \mathrm{Ni}, \mathrm{Cu}, \mathrm{Zn}, \mathrm{Rb}, \mathrm{Sr}, \mathrm{Ba}$, $\mathrm{Pb}, \mathrm{Zr}$, and As were analyzed by ARL 9800 series XRF.

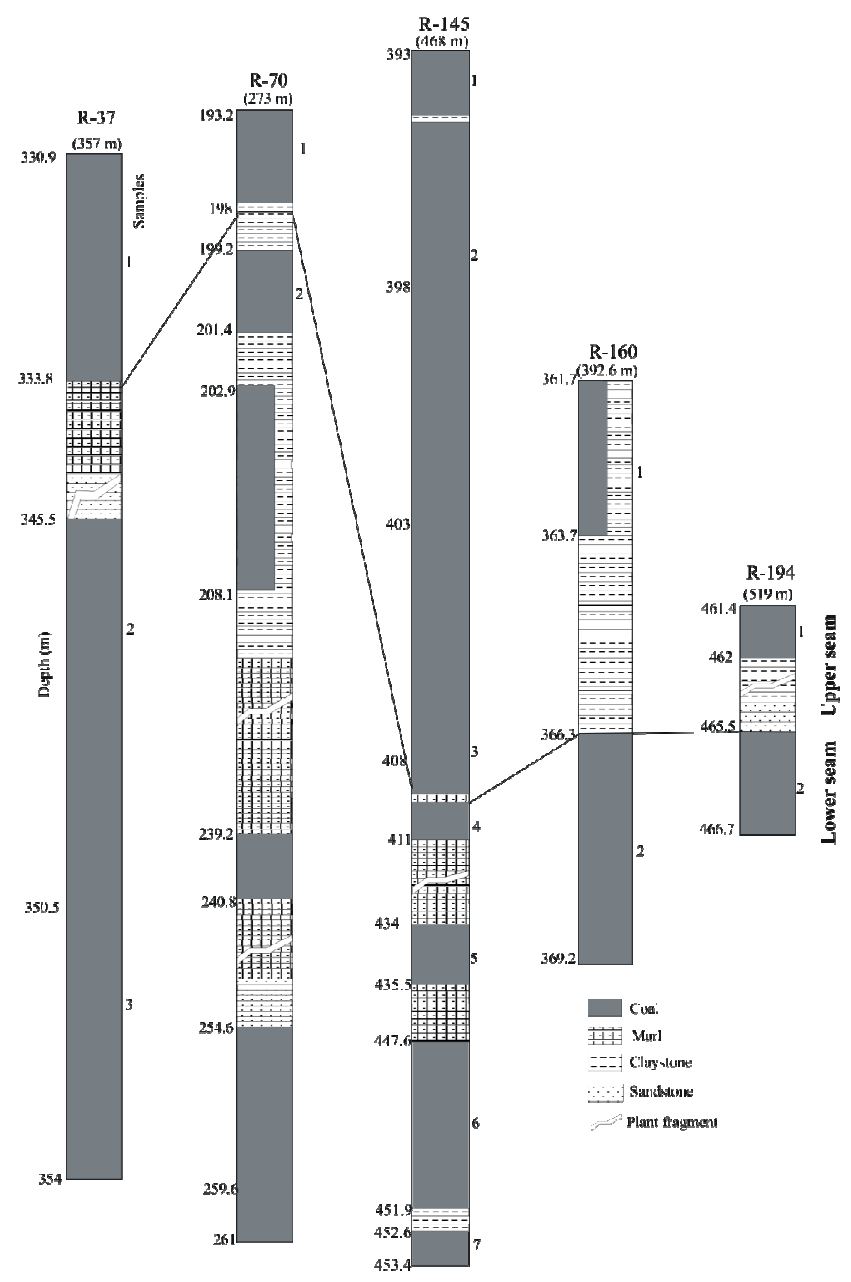

Figure 2. Sample locations studied in this study.

\section{Results And Discussion}

\subsection{Proximate Analyses}

Table 1 lists the results of proximate analyses of the Alpu coal samples in an air-dried basis. The total moisture contents of these coal samples range from $4.24 \%$ to $12.38 \%$ in the upper seam and $3.12 \%$ to $11 \%$ in the lower seam. The volatile matter values of the coal samples from the 
upper and the lower seam range from $17.40 \%$ to $60.17 \%$, and from $12.14 \%$ to $75.36 \%$, respectively. The ash contents in the upper and the lower coal seam range from $22.04 \%$ to $37.14 \%$, and from $19.85 \%$ and $43.12 \%$, respectively. The fixed carbon contents range from $9.66 \%$ to $33.09 \%$ in the upper coal seam and $1.47 \%$ to $38.62 \%$ in the lower coal seam. The total sulfur contents in upper and lower coal seams range from $1.26 \%$ to $7.44 \%$ and from $0.42 \%$ to
$3.05 \%$, respectively. The total calorific values range from $1640 \mathrm{kcal} / \mathrm{kg}$ to $4617 \mathrm{kcal} / \mathrm{kg}$ in the upper coal seam, and from $983 \mathrm{kcal} / \mathrm{kg}$ to $5531 \mathrm{kcal} / \mathrm{kg}$ in the lower coal seam. Average total moisture, ash, fixed carbon contents, and total calorific values in the upper coal seam are higher than those in the lower seam. However, the average value of volatile matter content in the lower coal seam is higher than in the upper seam.

Table 1. Proximate analysis results of Alpu coals.

\begin{tabular}{|c|c|c|c|c|}
\hline & Upper Seam & & Lower seam & \\
\hline \multicolumn{5}{|c|}{ Proximate analyses (air-dried basis) } \\
\hline Sample no & $\mathrm{N}=8$ & Average & $\mathrm{N}=9$ & Average \\
\hline Total moisture (\%) & $4.24-12.38$ & 8.13 & $3.12-11.00$ & 6.14 \\
\hline Volatile matter $(\%)$ & $17.40-60.17$ & 40.2 & $12.14-75.36$ & 46.27 \\
\hline Ash (\%) & $22.04-37.14$ & 30.8 & $19.85-43.12$ & 28.4 \\
\hline Fixed carbon $(\%)$ & $9.66-33.09$ & 20.9 & $1.47-38.62$ & 19.2 \\
\hline Total sulphur (\%) & $1.26-7.44$ & 2.6 & $0.42-3.05$ & 1.9 \\
\hline Gross cal. Val. (kcal/kg) & $1640-4617$ & 3215 & $983-5531$ & 2334 \\
\hline
\end{tabular}

\subsection{Geochemical Analyses}

\subsubsection{Major Elements}

Table 2 lists the major elemental compositions of the Miocene-aged Alpu coal samples. Geochemical analyses indicate that the average values of the major elemental concentrations show similarity between the seams. The contents of $\mathrm{Na}, \mathrm{Mg}, \mathrm{P}, \mathrm{K}, \mathrm{Ca}, \mathrm{Ti}, \mathrm{Mn}$, and $\mathrm{S}$ in the coal samples of the upper and the lower seam have nearly similar values. However, the average values of $\mathrm{Al}$ and $\mathrm{Fe}$ content are higher, and that of $\mathrm{Si}$ is lower in the upper seam compared with that in the lower seam.

Table 2 also compares the major elements in the coal samples from the upper and the lower seam with the average world coal contents [19], in which differences in concentrations are observed. The general trends are similar, although a clear enrichment is shown in both seams with respect to the average world coal contents (Figures $3 \mathrm{~A}$ and 3B). High major element concentrations in the Alpu coal samples show that these coals are probably low in rank.
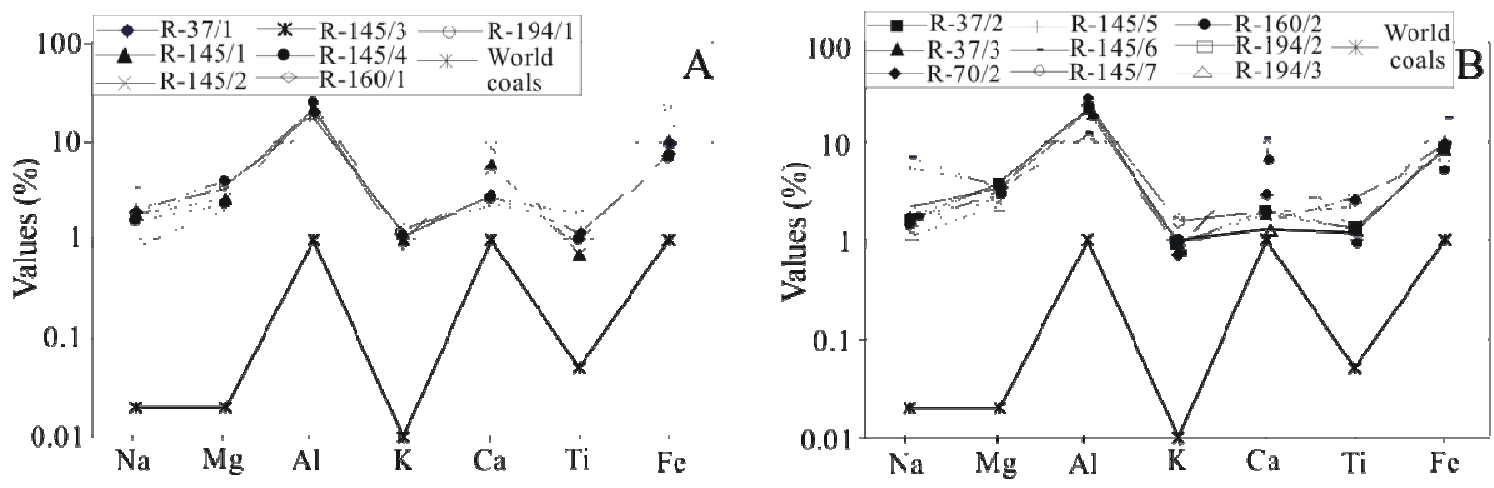

Figure 3. Diagrams of major element contents for Alpu coals and world average (A: Upper seam, B: Lower seam).
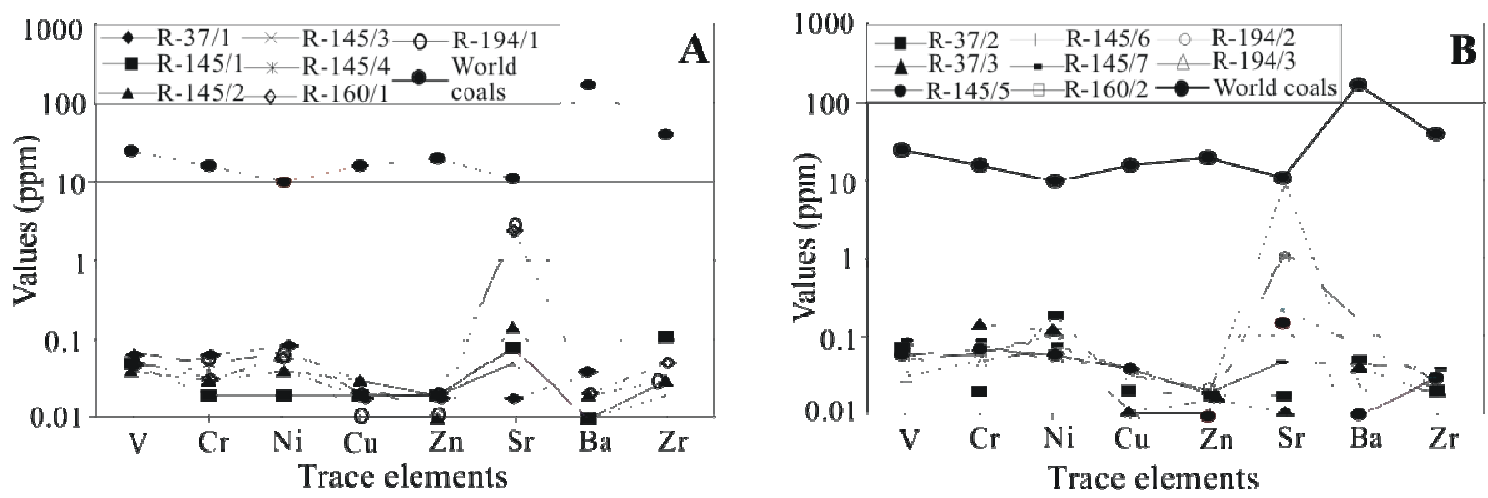

Figure 4. Diagrams of trace element contents for Alpu coals and world average (A: Upper seam, B: Lower seam). 
Table 2. Major element contents of Alpu coals and world coals average.

\begin{tabular}{|c|c|c|c|c|c|c|c|c|c|c|c|c|}
\hline & \multirow{2}{*}{$\begin{array}{l}\text { Sample } \\
\text { No }\end{array}$} & \multicolumn{11}{|c|}{ Major Elements (\%) } \\
\hline & & $\mathrm{Na}$ & Mg & Al & $\mathbf{S i}$ & $\mathbf{P}$ & $\mathbf{K}$ & $\mathrm{Ca}$ & $\mathbf{T i}$ & Mn & $\mathbf{F e}$ & $\mathbf{S}$ \\
\hline \multirow{8}{*}{ Upper Seam } & $\mathrm{R}-37 / 1$ & 2.04 & 4.08 & 20.70 & 57.60 & 0.10 & 1.12 & 2.96 & 1.22 & 0.10 & 7.86 & 2.23 \\
\hline & R-145/1 & 1.94 & 2.81 & 23.43 & 43.96 & 0.11 & 1.10 & 6.48 & 0.70 & $<0.1$ & 10.90 & 8.51 \\
\hline & $\mathrm{R}-145 / 2$ & 3.79 & 4.01 & 21.08 & 41.04 & 0.22 & 1.00 & 9.59 & 0.70 & $<0.1$ & 8.92 & 9.56 \\
\hline & $\mathrm{R}-145 / 3$ & 2.23 & 3.39 & 22.90 & 49.08 & 0.11 & 0.85 & 5.51 & 1.10 & $<0.1$ & 8.70 & 6.08 \\
\hline & $\mathrm{R}-145 / 4$ & 1.53 & 2.34 & 25.79 & 56.87 & 0.1 & 1.12 & 2.65 & 1.00 & $<0.1$ & 6.93 & 1.64 \\
\hline & $\mathrm{R}-160 / 1$ & 0.92 & 2.25 & 21.48 & 53.69 & 0.1 & 1.43 & 2.45 & 1.02 & $<0.1$ & 14.32 & 2.33 \\
\hline & R-194/1 & 1.76 & 3.52 & 17.29 & 44.92 & 0.12 & 1.20 & 2.69 & 1.86 & 0.10 & 23.30 & 3.22 \\
\hline & Average & 2.03 & 3.20 & 21.81 & 49.59 & 0.12 & 1.17 & 4.62 & 1.08 & 0.03 & 11.56 & 4.79 \\
\hline \multirow{10}{*}{ Lower Seam } & R-37/2 & 1.63 & 3.78 & 22.14 & 58.20 & 0.10 & 0.92 & 2.04 & 1.33 & $<0.1$ & 8.27 & 1.63 \\
\hline & $\mathrm{R}-37 / 3$ & 1.72 & 3.75 & 21.99 & 58.99 & 0.10 & 0.91 & 1.82 & 1.32 & $<0.1$ & 8.31 & 1.07 \\
\hline & R-70/2 & 1.43 & 3.17 & 27.43 & 49.65 & 0.10 & 0.72 & 2.97 & 2.50 & $<0.1$ & 9.73 & 2.24 \\
\hline & $\mathrm{R}-145 / 5$ & 5.56 & 3.93 & 18.43 & 42.31 & 0.11 & 0.87 & 8.40 & 1.20 & $<0.1$ & 9.50 & 9.60 \\
\hline & $\mathrm{R}-145 / 6$ & 7.35 & 3.62 & 13.73 & 26.44 & 0.11 & 0.77 & 11.10 & 1.10 & $<0.1$ & 18.76 & 17.90 \\
\hline & R-145/7 & 2.14 & 3.37 & 21.14 & 56.47 & 0.10 & 1.53 & 1.94 & 2.10 & $<0.1$ & 9.50 & 1.66 \\
\hline & R-160/2 & 1.97 & 3.39 & 22.28 & 45.76 & 0.11 & 0.98 & 8.74 & 0.98 & $<0.1$ & 6.12 & 6.96 \\
\hline & R-194/2 & 1.32 & 2.85 & 22.57 & 59.16 & 0.15 & 1.50 & 1.52 & 2.74 & $<0.1$ & 7.01 & 1.19 \\
\hline & R-194/3 & 1.13 & 2.26 & 12.22 & 69.23 & 0.20 & 1.00 & 1.34 & 1.23 & 0.20 & 9.76 & 1.40 \\
\hline & Average & 2.69 & 3.34 & 20.21 & 51.80 & 0.12 & 1.02 & 4.43 & 1.61 & 0.02 & 9.66 & 4.85 \\
\hline World coals* & & 0.02 & 0.02 & 1.00 & - & - & 0.01 & 1.00 & 0.05 & 0.05 & 1.00 & - \\
\hline
\end{tabular}

*From Valkovic (1983)

\subsubsection{Trace Elements}

Table 3 lists the trace element contents in the Alpu coal samples ( $\mathrm{V}, \mathrm{Cr}, \mathrm{Ni}, \mathrm{Cu}, \mathrm{Zn}, \mathrm{Rb}, \mathrm{Sr}, \mathrm{Ba}, \mathrm{Pb}, \mathrm{Zr}$, and $\mathrm{As}$ ). Concentrations of As (except R-37/1, R70-2), Rb, and $\mathrm{Pb}$ (except R-37/1, R-37/2, and R-37/3) in the upper and the lower seam are below the detection limit. The average values of $\mathrm{V}, \mathrm{Cr}, \mathrm{Ni}, \mathrm{Cu}, \mathrm{Zn}, \mathrm{Rb}, \mathrm{Ba}, \mathrm{Pb}$, and $\mathrm{Zr}$ in the coal samples indicate similarity between both two seams. However, the $\mathrm{Sr}$ content from the upper seam is lower than that from the lower seam.

Table 3 compares the trace elements in the coal samples from the two seams with the average world coal contents [20]. The trace element contents from both seam coals are highly depleted with respect to world coal contents (Figures 4A and 4B). The coal samples have low trace element concentrations because of the absence of a volcanic source $[21,8]$.

Table 3. Trace element contents of Alpu coals and world coals average.

\begin{tabular}{|c|c|c|c|c|c|c|c|c|c|c|c|c|}
\hline & \multirow{2}{*}{ Sample No } & \multicolumn{7}{|c|}{ Trace Elements (ppm) } & \multirow[b]{2}{*}{$\mathbf{B a}$} & \multirow[b]{2}{*}{$\mathbf{P b}$} & \multirow[b]{2}{*}{ As } & \multirow[b]{2}{*}{$\mathbf{Z r}$} \\
\hline & & $\mathbf{V}$ & $\mathrm{Cr}$ & $\mathrm{Ni}$ & $\mathrm{Cu}$ & $\mathbf{Z n}$ & $\mathbf{R b}$ & $\mathrm{Sr}$ & & & & \\
\hline \multirow{8}{*}{ Upper Seam } & R-37/1 & 0.07 & 0.07 & 0.09 & 0.02 & 0.02 & 0.01 & 0.02 & 0.05 & 0.01 & 0.01 & $<0.01$ \\
\hline & $\mathrm{R}-145 / 1$ & 0.05 & 0.02 & 0.02 & 0.02 & 0.02 & - & 0.08 & 0.01 & - & - & 0.11 \\
\hline & $\mathrm{R}-145 / 2$ & 0.04 & 0.03 & 0.04 & 0.03 & 0.01 & - & 0.14 & 0.02 & - & - & 0.03 \\
\hline & $\mathrm{R}-145 / 3$ & 0.07 & 0.05 & 0.07 & 0.03 & 0.02 & - & 0.08 & 0.01 & - & - & 0.02 \\
\hline & $\mathrm{R}-145 / 4$ & 0.05 & 0.04 & 0.04 & 0.02 & 0.02 & - & 0.05 & 0.01 & - & - & 0.03 \\
\hline & $\mathrm{R}-160 / 1$ & 0.05 & 0.04 & 0.06 & 0.02 & 0.02 & - & 2.28 & 0.02 & - & - & 0.05 \\
\hline & R-194/1 & 0.05 & 0.06 & 0.06 & 0.01 & 0.01 & - & 3.11 & & - & - & 0.03 \\
\hline & Average & 0.05 & 0.04 & 0.05 & 0.02 & 0.02 & 0.001 & 0.82 & 0.02 & 0.001 & 0.001 & 0.04 \\
\hline \multirow{10}{*}{ Lower Seam } & $\mathrm{R}-37 / 2$ & 0.07 & 0.02 & 0.18 & 0.02 & 0.02 & 0.01 & 0.02 & 0.05 & 0.01 & - & 0.02 \\
\hline & $\mathrm{R}-37 / 3$ & $<0.01$ & 0.14 & 0.12 & 0.01 & 0.01 & 0.01 & 0.01 & 0.04 & 0.01 & - & 0.02 \\
\hline & $\mathrm{R}-70 / 2$ & 0.06 & 0.06 & 0.09 & 0.03 & 0.02 & - & 0.08 & 0.01 & - & 0.03 & 0.11 \\
\hline & R-145/5 & 0.06 & 0.07 & 0.06 & 0.04 & 0.01 & - & 0.15 & 0.01 & - & - & 0.03 \\
\hline & $\mathrm{R}-145 / 6$ & 0.06 & 0.06 & 0.06 & 0.04 & 0.02 & - & 0.23 & $<0.01$ & - & - & 0.03 \\
\hline & $\mathrm{R}-145 / 7$ & 0.09 & 0.09 & 0.08 & 0.04 & 0.02 & - & 0.05 & $<0.01$ & - & - & 0.04 \\
\hline & $\mathrm{R}-160 / 2$ & 0.05 & 0.06 & 0.10 & 0.03 & 0.02 & - & 8.87 & 0.02 & - & - & 0.02 \\
\hline & R-194/2 & 0.08 & 0.08 & 0.05 & 0.04 & 0.02 & - & 1.17 & - & - & - & 0.04 \\
\hline & R-194/3 & 0.03 & 0.05 & 0.07 & 0.01 & 0.01 & - & 1.36 & - & - & - & 0.02 \\
\hline & Average & 0.06 & 0.07 & 0.09 & 0.03 & 0.02 & 0.002 & 1.33 & 0.01 & 0.002 & - & 0.04 \\
\hline World Coals ${ }^{*}$ & & 22 & 15 & 9 & 15 & 18 & 10 & 10 & 150 & 6.6 & 7.6 & 345 \\
\hline
\end{tabular}

*From Ketris and Yudovich (2009)

\subsection{Affinity of the Elements}

Coal is a sedimentary rock and a complex heterogeneous mixture of organic matter and inorganic components. The correlation of the element contents with the ash yield of coal may offer information for its organic or inorganic affinity [22, 23]. For coal samples with high ash contents, elements are mostly associated with inorganic components [24]. The amount of organically bound elements increases for coals with decreasing ash content, whereas the 
abundance of inorganically bound elements decreases [25, 26]. Al and Si contents in both coal seams have positive correlations with ash yield $(r=0.62$ for upper seam (Us), 0.69 for lower seam (Ls), and $\mathrm{r}=0.80$ for Us, 0.77 for Ls, respectively) at 95\% confidence level (Figure 5). These elements are generally associated with inorganic components. Silisium has affinity with clastic minerals, and Al has aluminosilicate and feldspar affinities. Figure 5 also shows that the ash yields in the lower coal seams have positive correlations with $\mathrm{K}, \mathrm{P}, \mathrm{Ti}$, and $\mathrm{S}(\mathrm{r}=0,36,0,35,0,37$, and 0.63 ; at $95 \%$ confidence level). These elements are dominantly and inorganically associated. $\mathrm{K}$ has aluminosilicate and feldspar, $\mathrm{S}$ has sulfide, Ti has clay or FeTi-oxide minerals, and $\mathrm{P}$ has apatite affinity. However, these contents in the upper coal seam have negative correlations with the ash yield $(\mathrm{r}=-0.32,-0.25,-0.41$, and -0.36 ; at 95\% confidence level Figure 5). Yossifova et al. [5] indicated that organic matter increases the abundance of $\mathrm{Ti}$ and $\mathrm{S}$ into the bog. $\mathrm{S}$ and $\mathrm{K}$ are found in both organic and inorganic matter. Ash yields of the coal samples in upper and lower seams have negative correlations with $\mathrm{Mg}$, $\mathrm{Na}, \mathrm{Ca}$, and $\mathrm{Fe}(\mathrm{r}=-0.18$ for Us and -0.37 for $\mathrm{Ls}, \mathrm{r}=-0.26$ for Us and $\mathrm{r}=-0.63$ for Ls, $\mathrm{r}=-0.26$ for $\mathrm{Us}$ and $\mathrm{r}=-0.72$ for Ls, and $\mathrm{r}=-0.78$ for Us and $\mathrm{r}=-0.36$ for Ls, respectively; at $95 \%$ confidence level, Figure 5). $\mathrm{Na}$ is mainly abundant in organic matter [5]. $\mathrm{Fe}$ is generally associated with inorganic components, but studies have indicated that this element has intermediate organic affinity in coal $[27,28,29$, $22,23] . \mathrm{Mg}$ is mainly related to clay and ferromagnesian minerals. $\mathrm{Ca}$ is characterized by carbonate affinity. However, studies have shown that $\mathrm{Mg}$ in some coal samples has organic affinity [27, 30, 31, 32, 33,34, 35, 22]. Thus, Ca may also be found in organic matter [36]. Figure 6 shows that the concentrations of $\mathrm{Ni}$ and $\mathrm{Ba}$ in coal samples from both seams are positively correlated with the ash yield $(r=0.32$ for Us and $r=0.25$ for $L s$, and $r=0.52$ for Us and $\mathrm{r}=0.35$ for Ls, respectively; at $95 \%$ confidence level). These elements have inorganic affinity.
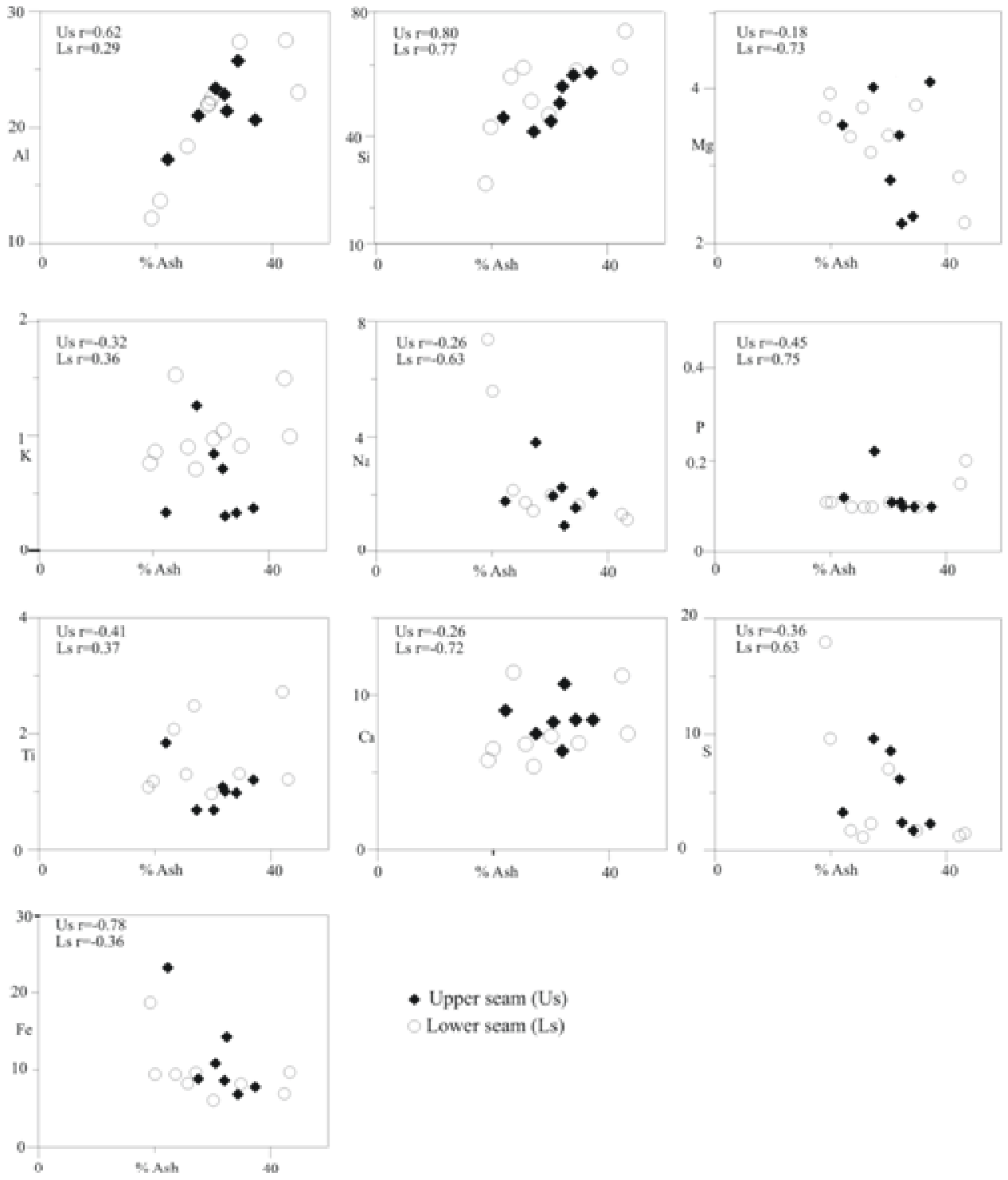

- Upper seam (Us)

Lower seam (Ls)

Figure 5. Relation between major element concentrations and ash yield. 

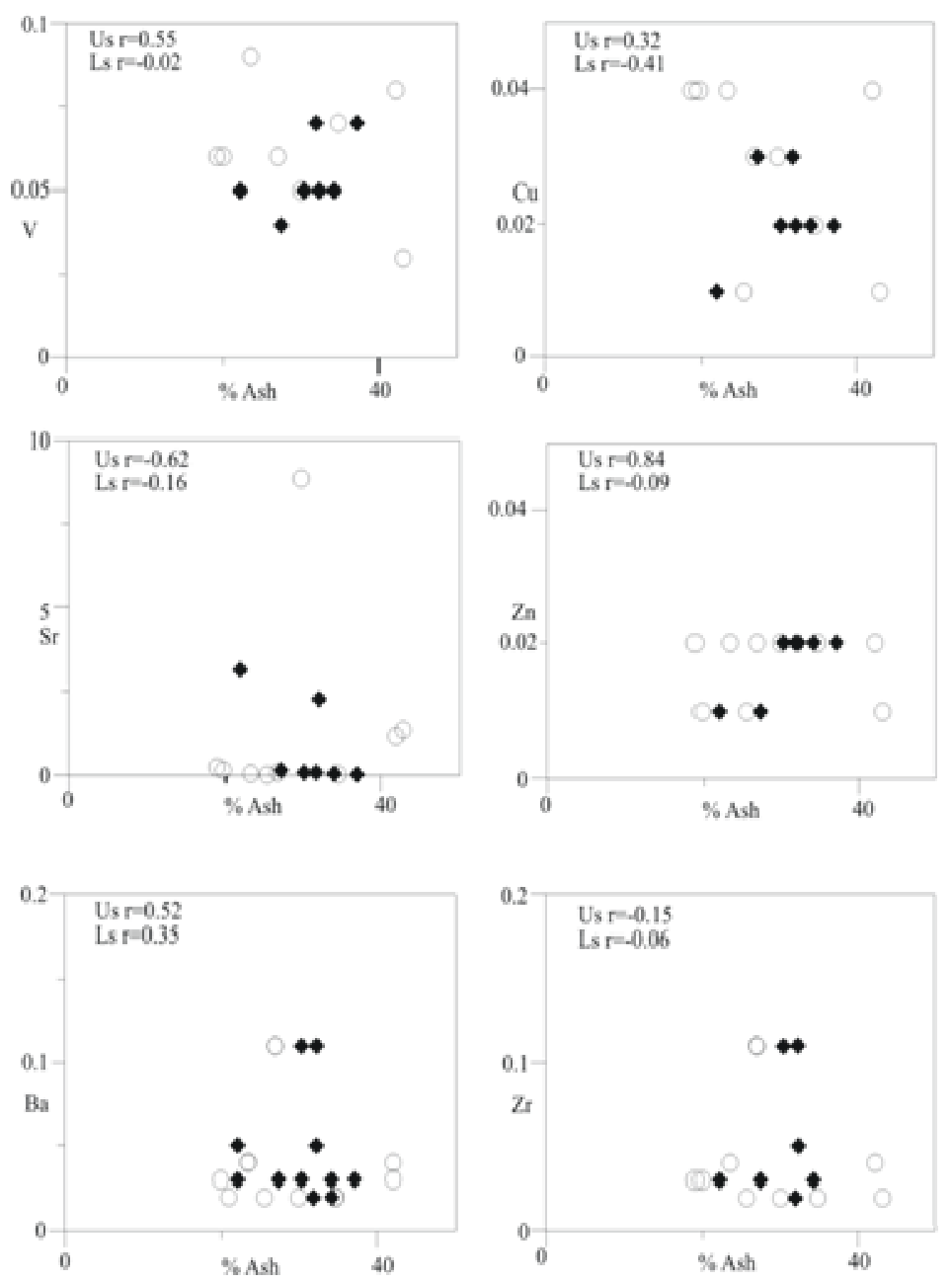
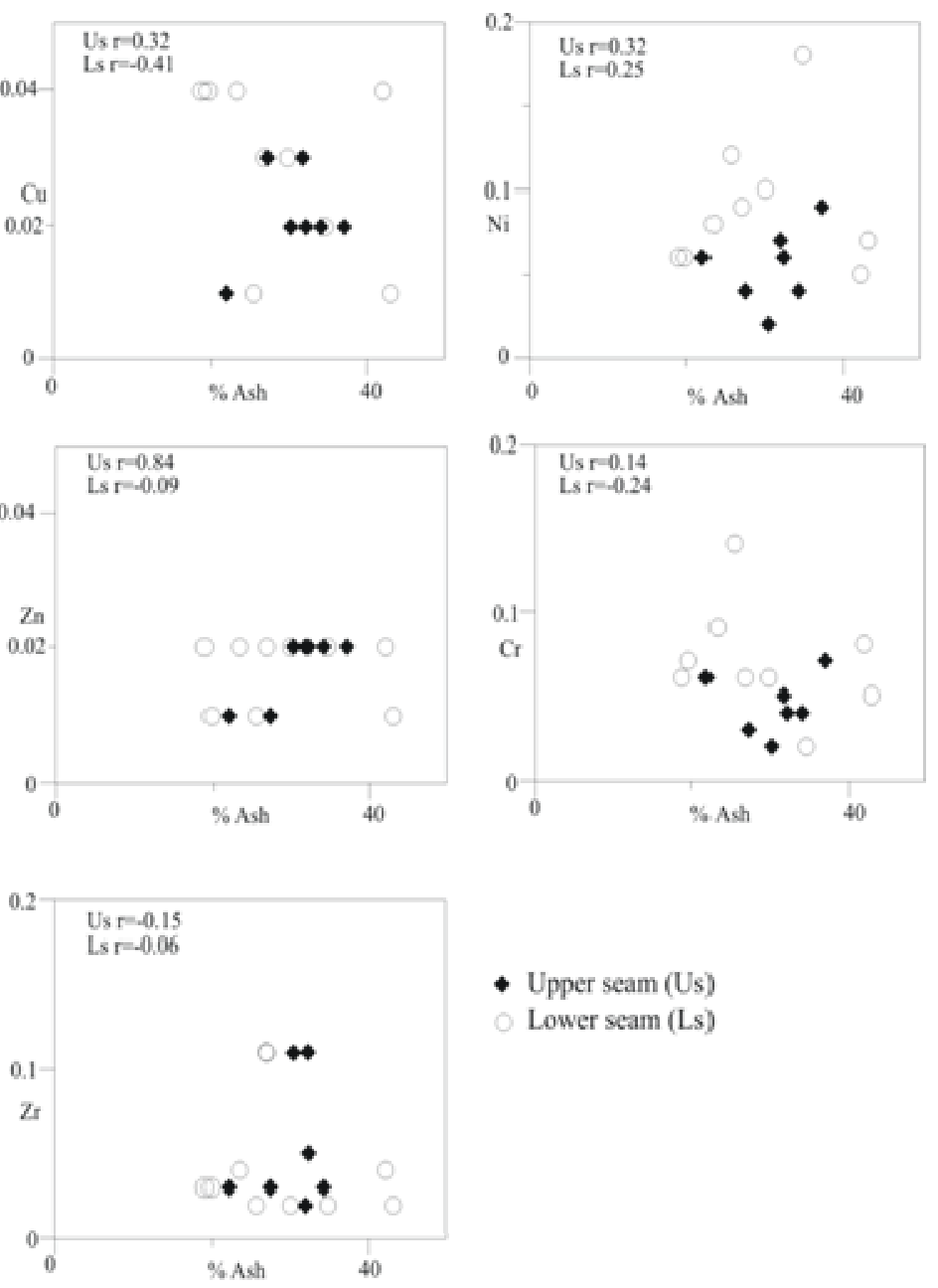

- Upper seam (Us)

Lower seam (Ls)

Figure 6. Relation between trace element concentrations and ash yield.

Figure 6 also shows that the ash yields in coal samples from the upper seam have positive correlation with $\mathrm{Zn}, \mathrm{Cu}$, $\mathrm{Cr}$, and $\mathrm{V}(\mathrm{r}=0.84,0.32,0.14$, and 0.55 , respectively; at $95 \%$ confidence level), suggesting a mineral matter affinity. Zn is mainly associated with the inorganic components in coal $[12,13,14]$. The organic associations of $\mathrm{Zn}$ have also been determined in low-ranked coals $[15,13,16]$. $\mathrm{Cu}$ and $\mathrm{Cr}$ in coal have organic affinity $[17,13,8]$. In addition, $\mathrm{V}$ in coal is associated with both inorganic and organic matter [17, 13]. Figure 6 further shows that the concentrations of $\mathrm{Sr}$ and $\mathrm{Zr}$ in both coal seams are negatively correlated with the ash yield $(\mathrm{r}=-0.62$ for Us and -0.16 for Ls, and $\mathrm{r}=-0.15$ for Us and -0.16 for Ls; at $95 \%$ confidence level), showing the association of these elements with organic matter. $\mathrm{Zr}$ is commonly associated with organic matter $[17,13]$. The $\mathrm{Sr}$ is mainly found together with mineral matter (phosphate and carbonate minerals), and is associated with organic matter in low-ranked coals $[17,13,18,8]$.

\section{Conclusions}

Volatile matter, ash, fixed carbon, total sulfur contents, and total calorific values are higher in the upper seam than those in the lower seam on an air-dried basis. However, the volatile matter contents are lower in the upper seam than in the lower seam. The average values of major element concentrations demonstrate similarity in both seams. However, the average $\mathrm{Al}$ and $\mathrm{Fe}$ concentrations are higher in the upper seam, and the average $\mathrm{Si}$ concentration is higher in the lower seam. The major elements in the coal samples from both seams differ from the world coal contents. Although a clear enrichment appears in both seams with respect to world coal contents, the general trends are similar. The $\mathrm{Al}$ and $\mathrm{Si}$ contents in both coal seams have inorganic affinity because of the positive correlations with the ash yield. The concentrations of $\mathrm{Mg}$, $\mathrm{Na}, \mathrm{Ca}$, and $\mathrm{Fe}$ in both seams have negative correlations with the ash yield. Thus, these elements are associated with organic matter in coal. Ash yields from the lower coal seam samples have positive correlations with $\mathrm{K}, \mathrm{P}, \mathrm{Ti}$, and $\mathrm{S}$, indicating inorganic affinity. However, these elements in the upper coal seam have negative correlations with ash yield. Thus, K, P, Ti, and S contents in the upper coal seam are organically associated. The average values of $\mathrm{V}, \mathrm{Cr}, \mathrm{Ni}$, $\mathrm{Cu}, \mathrm{Zn}, \mathrm{Rb}, \mathrm{Ba}, \mathrm{Pb}$, and $\mathrm{Zr}$ in the coal samples show similarity for both seams. However, the Sr content in the lower coal seam is higher than that in the upper coal seam. The trace element contents of these seams are highly 
depleted with respect to the world coal contents. $\mathrm{Ni}$ and $\mathrm{Ba}$ contents in both coal seams are positively correlated with ash yield, indicating that these elements have inorganic affinity. The concentrations of $\mathrm{Sr}$ and $\mathrm{Zr}$ in both coal seams are negatively correlated with the ash yield, which implies association with organic matter. The ash yield of the coal samples in the upper seam has positive correlations with $\mathrm{Zn}$, $\mathrm{Cu}, \mathrm{Cr}$, and $\mathrm{V}$, which indicate mineral matter affinities. Proximate and geochemical analyses imply that the Miocene-aged coal samples in Alpu are low in rank.

\section{Acknowledgements}

The authors thank to the staff to General Directorate of MTA for proximate and geochemistry analyses.

\section{References}

[1] Koniarov, G., 1932. The Brown Coals in Bulgaria. Issue of the Government Pernik Mines. 303 pp. (in Bulgarian).

[2] Minchev, D., 1962. Petrology of Bulgarian Brown coals, petrographical investigations of Chukurovo coal basin. Livre 2- Geologie 56. Annuaire de l'Universite de Sofia, pp. 1-69 (in Bulgarian with German abstract).

[3] Falcon-Lang, H.J., 2006. A history of research at the Jogging Fossil Cliffs of Nova Scotia, Canada, the world's finest Pennsylvanian section. Proceedings of Geologists2 Association 117, 377-392.

[4] Erdei, B., Dolezych, M., Hably, L., 2009. The buried Miocene forest at Bükkábrány, Hungary. Review of Paleobotany and Palynology 155, 69-79.

[5] Yossifova, M. G., Eskenazy, G. M., Valceva, S. P., 2011. Petrology, mineralogy, and geochemistry of submarine coals and petrified forest in the Sozopol Bay, Bulgaria. International Journal of Coal Geology 87, 212-225.

[6] Vassilev, S. V., Vassileva, C. G., 2009. A new approach fort he combined chemical and mineral classification of the inorganic matter in coal. 1. Chemical and mineral classification systems, Fuel 88, 235-245.

[7] Gentzis, T., Goodarzi, F., 1997. Selected elements and radionuclides in thermal coals from Alberta. Can. Energy Sources 19, 259-269.

[8] Karayiğit, I. H., Gayer, R. A., Querol, X., and Onacak, T., 2000. Contents of major and trace elements in feed coals from Turkish coal-fired power plants. Intl. J. Coal Geol. 44, 169-184.

[9] Siyako, F., Coşar, N., Çokyaman, S. ve Coşar, Z., 1991. Tertiary Geology of Bozüyük-İnönü-Eskişehir-AlpuBeylikova-Sakarya Wastes and Coal Possibilities. MTA Report No. 9281 (unpublished), Ankara.

[10] Gözler, Z. Cevher, F., Ergül, E. ve Asutay, J. H., 1997. Geology of Middle and South of Sakarya, (unpublished),

[11] Şengüler, İ., 2011. Neogene Geology of Eskişehir Sivrihisar Basin and Potential of Coal. MTA Report No. 993, (unpublished), Ankara.
[12] Finkelman, R.B., 1981. Modes of occurence of trace elements in coals. US Geol. Surv. Open File Report No OFR-81-99, $301 \mathrm{p}$.

[13] Finkelman, R.B., 1995. Modes of occurences of environmentally-sensitive trace elements in coal. In: Environmental Aspects of Trace Elements in Coal. Swaine, D. J., Goodarzi, F. (eds), The Netherlands: Kluwer Academic Publishers, pp. 24-44.

[14] Orem, W. H., Finkelman, R. B., 2003. Coal and geochemistry. In: Treatise on Geochemistry. Holland, H. D., Turekian, K. K. (eds.), Amsterdam, Elsevier, pp. 191-222.

[15] Zubovic, P., Stadnichenko, T., and Sheffey, N. B., 1960. The association of minor elements with organic and inorganic phases in coal. US Geol. Surv. Prof. Pap. 400, 84-87.

[16] Kara-Gulbay, R., Korkmaz, S., 2009. Trace Elements Geochemistry of the Jurassic Coals in the Feke and Kozan (Adana) Areas, Eastern Taurides, Turkey. Energy Sources, Part A, 31 1315-1328.

[17] Swaine, D. J., 1990. Trace Elements in Coal. Butterworrths, London, p. 278.

[18] Ward, C. R., Spears, D. A., Booth, C. A., Staton, I., Gurba, L. W. 1999. Mineral matter and the elements in coal of the Gunnedah Basin, New South Wales, Australia. Int. J. Coal. Geol. 40, 231-308.

[19] Valkovic, V. 1983. Trace elements in coal. Boca Raton, FL: CRC Press, pp. 210-281.

[20] Ketris, M.P., Yudovich, Ya.E., 2009. Estimations of Clarkes for Carbonaceous biotithes: World averages for trace element contents in black shales and coals. Intl. J. Coal Geol.78, 135-148.

[21] Gayer, R.A., Karayigit, A.I., Goldsmith, S., Onacak, T., Rose, M., 1998. Trace elements geochemistry of feed coals, fly and bottom ashes of Turkish power plants: implications for ash utilization. In: Proceedings of the 8th Australian Coal Science Conference, December. Pp.339-344.

[22] Kortenski, J., Sotirov, A., 2002. Trace and major elements content and distribution in Neogene lignite from the Sofia Basin, Bulgaria. International Journal of Coal Geology 52, 63-82.

[23] Dai, S., Ren, D., Tang, Y., Yue, M., Hao, L., 2005. Concentration and distrubition of elements in Late Permian coals from western Guizhou Province, China. Intl. J. Coal Geol 61, 119-137.

[24] Swaine, D. J., 1995. The contents and some related aspects of trace elements in coals. In: Environmental Aspects of Trace Elements in Coal. Swaine, D. J., Goodarzi, F. (eds), London, Kluwer Academic Publishers, pp. 5-19.

[25] Nicholls, G. D., 1968. The geochemsitry of coal-bearing strata. In: Coal and Coal Bearing Strata. Murchison, H. D., Turekian, K. K. (eds.), Edinburg: Oliver and Boyd, pp. 269-307.

[26] Gluskoter, H., Ruch, R., Miller, W., Cahill, R., Dreher, G., Kuhn, J., 1977. Trace elements in coal: occurrence and distribution. Circular-Illinois State Geological Survey 499, 155p.

[27] Song, D., Qin, Y., Zhang, J., Wang, W., Zheng, C., 2007. Concentration and distribution of trace elements in some coals from Nothern China. Intl. J. Coal Geol. 69, 179-191. 
[28] Kuhn, J. K., Fiene, F.L., Cahill, R. A., Gluskoter, H. J., Shimp, N. F., 1980, Abundance of trace and minor elements in organic and mineral fractions of coal. Illinois State Geological Survey 88, 67p.

[29] Querol, X., Fernandez Turtle, J. L., Lopez-Soler, A., Duran, M. E., 1992. Trace elements in high-sulfur sub-bituminous coals of the their bearing during coal combustion. 2nd Report, European Coal and Steel Community Project 7220/ED/014.33p.

[30] Pareek, H.S., Bardhan, B., 1985. Trace elements and their variation along seam profiles of the Middle and Upper Barakar Formations (Lower Permian) in the East Bokaro coal field, district Hazaribag, Bihar, India. Int. J. Coal Geology 5, 281-314.

[31] Miller, R.N., Given, P.H., 1987. The association of major, minor and trace inorganic elements with lignites: III. Trace elements in four lignites and general discussion of all data from this study. Geochimica et Cosmochimica Acta 51, $1843-1853$
[32] Eskenazy, G., 1996. Factors controlling the accumulation of trace elements in coal. Annual of Sofia University 89, 219236

[33] Querol, X., Cabrera, L1., Pickel, W., Lopez-Soler, A., Hagemann, H.W., Fernandez-Turiel, J.L., 1996. Geological controls on the coal quality of the Mequinenza subbituminous coal deposit, northeast Spain. Int. J. Coal Geology 29,57-91.

[34] Querol, X., Whateley, M.K.G., Fernandez-Turiel, J.L., Tuncali, E., 1997a. Geological controls on the mineralogy and geochemistry of the Beypazary lignite, central Anatolia, Turkey. Int. J. Coal Geology 33, 255-271.

[35] Vassilev, S.V., Eskenazy, G.M., Vassileva, Ch.G., 2001. Behavior of elements and minerals during preparation and combustion of the Pernik coal, Bulgaria. Fuel Processing Technology 72, 103-129.

[36] Finkelman, R.B., 1994. Modes of occurrence of potentially hazardous elements in coal: Level of confidence. Fuel Proc. Technol. 39, 21-34. 